\title{
Linearne i cykliczne procesy formacyjno- -socjalizacyjne w społeczeństwie i w środowisku akademickim a niepełnosprawność
}

Wstęp

Orzekanie o istnieniu jednej i niezmiennej zasady, która mogłaby determinować przebieg rozwoju życia społecznego, jest skazane na niepowodzenie. Kontestowanie takiego orzekania nie niweluje jednak poszukiwania. Wysiłek poznawczy i interpretacyjny, by to czynić, jest jednak wartościowy. Istnieje przekonanie o tym, że życie, funkcjonowanie i dobrostan jakiejś małej, wydzielonej i „fragmentarycznej” rzeczywistości (jakkolwiek zawsze złożonej z jednostek) jest istotnie skorelowane $\mathrm{z}$ funkcjonowaniem zbiorowości (wspólnoty) w szerszym znaczeniu: jako społeczeństwa. Podobnie gdy idzie o wybór metody, którą można by posługiwać się dla opisywania, wyjaśniania i nakreślania horyzontów metamorficznych jednej i drugiej postaci rzeczywistości. Wybór miałby dotyczyć opcji socjologicznego metrum badawczego: empirycznego lub humanistycznego. Dla niektórych wybór ten jest dylematem, nierozwiązywalnym w możliwości ich zintegrowania. Dlatego przytoczony przez Stanisława Ossowskiego i dziś znajduje 
138 uzasadnienie: rzekoma konieczność wyboru między efektami badań ścisłych, lecz błahych, a tymi, o których można powiedzieć, iż są ważne, lecz niepewne ${ }^{1}$. Do tego nienowego już przecież sporu i wynikającej z niego rzekomej konieczności wyboru dołącza kwestia wierności tradycji i konieczności podążania za nowością i oryginalnością. Czy jednak konformistyczne przylgnięcie do trendów nowości będzie symptomem oryginalności, pomysłowości i kreatywności? Sprawa wydaje się wątpliwa. W niniejszym artykule większe uzasadnienie i wybór tej drugiej opcji nie jest odrzuceniem ważności tej pierwszej (nawet jeśli się do niej bezpośrednio nie nawiązuje). Postrzeganie zjawiska maturacjonizmu, który jako proces dojrzewania spoleczeństwa i jednostki otwiera się zarówno na nowości, jak i dziedzictwo przeszłości; który łączy je ze sobą, dalekie jest zarówno od dyktatu potrzeby erudycji, jak i „tyranii nowości”2 i mody, nieomijającej i uprawiania nauki, w tym socjologii. Gdy wskaże się dodatkowo edukację uczelnianą oraz kwestię niepełnosprawności, powyższa perspektywa wydaje się tym bardziej uzasadniona.

\section{Linearno-cykliczna logika rozwoju jednostkowo-społecznego - maturacjonizm}

\subsection{Trajektorie rozwojowe}

Kontynuując myśl zawartą we wstępie, należy z przekonaniem stwierdzić, iż wątpliwe wydaje się przeświadczenie o tym, że istnieje jeden i jedynie słuszny paradygmat rozwojowy społeczeństwa. W sensie teoretycznym jest to uzasadnione, ponieważ kreatywność przedstawicieli nauk społecznych jest wciąż nowa, a każdy wysiłek kreślenia własnego rozumienia rozwoju jest w jakimś sensie wartościowy i w pewnym zakresie przyczynia się do kumulacji wiedzy w tej dziedzinie. Tym bardziej gdy spojrzy się na historyczno-społeczny przebieg procesów rozwojowych społeczeństw, zauważalny staje się nierzadko autorski, sprawczy i specyficzny charakter trajektorii rozwojowych. Począwszy od podstawowych paradygmatów rozwojowych, takich choćby jak teoria modernizacji (realizowana w praktyce), sugerująca konieczność

1 Por. S. Ossowski, O nauce, Warszawa 1967, s. 247.

2 A. Lipski, O kłopotach teoretyczno-metodologicznych pogranicza w naukach społecznych, „Problemy Polityki Społecznej” 22 (2013) 3, s. 72. 
homogenicznego podążania drogą rozwoju (odtwarzanie i transfer ustalonego i sprawdzonego modelu będącego w domenie świata Zachodu), po najbardziej i dość uniwersalnie podzielany jako trafny model ustrojowy demokrację ${ }^{3}$. Nie istnieje tym bardziej wyczerpująca i adekwatna do heterogenicznych manifestacji rozwojowych definicja, która, arbitralnie określona, miałaby wskazywać na stały i jednorodnie biegnący proces udoskonalania. Taką logikę hermeneutyczną można co najwyżej odnieść do rozwoju technologicznego.

Rozwój człowieka, wychowanie człowieka, wprowadzanie go do społeczeństwa ${ }^{4}$ są ukierunkowane na przyszłość, choć opierają się na stanie aktualnym. Jest on taki, jakim go postrzega i potrafi opisać obserwator oraz jaki objawia się introjekcyjnie i refleksyjnie samej zainteresowanej osobie. Nie jest on efektem ślepego determinizmu, prowidencjalizmu i ogólnodziejowego fatum. Jest raczej wypadkową sprzężenia i współdziałania determinacji strukturalnej i sprawczości jednostkowej, która się zaktualizowała poprzez mechanizm chronologicznie kształtującej się przeszłości. Nawet jeśli podmiot działałby jednak pod silnym wpływem agend socjalizacyjnych, w swoim postępowaniu wykazując się cechami „naiwniaka kulturowego" - jak trafnie zauważa Margaret S. Archer - będzie odgrywał swoje role kompetentnie, lecz z dystansem, wykazując się swoistą wirtuozerią, realizując społeczne performance, ale przede wszystkim wykazując się silnie ukształtowaną (bądź kształtującą się) tożsamością osobistą ${ }^{5}$. Ta z kolei nie jest ślepo i arbitralnie narzuconą formą presji socjalizacyjnej i kulturowej. Czy wszystkie mechanizmy uczelniane ukierunkowane na wsparcie osób z niepełnosprawnościami nie wykazują się także takimi pozytywnie rozumianymi „ograniczeniami”, uwzględniającymi tożsamość i sprawczość wspomnianych osób (studentów), nierzadko zaskakujących

3 Można podać jako przykład - jeden z wielu - w jaki sposób gasną i odżywają na nowo pewne idee, pomysły, projekty, które to czasem zostają uniwersalnie okrzyknięte jako zdezaktualizowane (nawet jeśli nie towarzyszy temu kontekst ideologiczny), a mimo to ich rewitalizacja i ponowne wyłanianie się stają się faktem; niechby posłużyła za przykład idea spółdzielczości, związana z przedsiębiorczością, kreatywnością i komunitarianizmem; mogłoby się wydawać, że w Polsce po przełomie 1989 roku idea spółdzielczości powinna odżyć z nowa siłą, a jednak była to zmiana, która podcięła zupełnie jej korzenie; dopiero na początku XXI stulecia spółdzielczość stała się przedmiotem szczególnego zainteresowania i wsparcia; zob. A. Piechowski, Edukacja i szkolenie w dziejach polskiej spółdzielczości, „Problemy Polityki Społecznej” 2 (2013) 1, s. 89-106.

4 Por. P. Sztompka, Socjologia. Analiza społeczeństwa, Kraków 2012, s. 450.

5 Por. M. S. Archer, Człowieczeństwo. Problem sprawstwa, przeł. A. Dziuban, Kraków 2013, s. 81 . 
140 ową kompetencją kontekst akademicki, wprowadzających nawet w zawstydzenie pozostałą część środowiska (pełnosprawnego jego segmentu)?

\subsection{Pozaczasowe spotkanie wymiarów czasu w edukacji}

Ze szczególną wyrazistością ów rys spotkania przeszłości, teraźniejszości i wychylenia przyszłościowego potwierdza logika przebiegu procesów wychowania, socjalizacji, edukacji, w tym tej, która dokonuje się w rzeczywistości uczelni wyższych. Florian Znaniecki dostrzega w uniwersalnie (horyzontalnie i wertykalnie) postrzeganym wychowaniu pewne charakterystyczne czynności (bezrefleksyjne i refleksyjne), dokonywane przez określonych ludzi (jednostkowo i instytucjonalnie), z zamierzeniem spowodowania, inhibicji lub skorygowania, w najbliższym czasie lub w dalszej przyszłości, określonych zachowań i czynności ludzi, których uczynili „przedmiotem” takich oddziaływań ${ }^{6}$. Wychowawca (wychowujące społeczeństwo) ma "materiał wychowawczy”, „bazę socjalizacyjną”, „substancję edukacyjną" (czego nie chcemy rozumieć przedmiotowo, jedynie jako ogół tego wszystkiego, co staje się źródłem i powodem procesów wychowawczo-socjalizacyjnych), którą diagnozuje i względem której zamierza podjąć adekwatne działania. Ma świadomość, że wcześniej jakiś proces socjalizacyjno-wychowawczy już się dokonał. Nie zna do końca jego rzeczywistych poziomów. Raczej zakłada, iż nie jest on odpowiedni, skoro sam (często pod wpływem presji społeczeństwa, które uczyniło go podmiotem aktywności wychowawczych) podejmuje się jego kontynuacji, będącej zasadniczo uznaną za rzeczywisty początek tego procesu (stan aktualny).

Jak rzadko która działalność mająca na celu wywieranie wpływu na inne osobniki, działalność wychowawczo-socjalizacyjna jest ukierunkowana na przyszłość. Wychowanie z zasady jest procesem długofalowego drążenia, kształtowania, formowania. Przy całym krytycznym ustosunkowaniu się do aktywności wychowawczo-socjalizacyjnych, przy wykazywaniu błędów dokonywanych $\mathrm{w}$ tym obszarze rzadko kiedy zarzuca się podmiotom wychowawczym nieświadomość przyszłościowego ukierunkowania. Nawet gdy uwzględni się planowany odgórnie proces edukacyjny, oświatowy (choćby publiczny sektor szkolnictwa), i wskaże na liczne zaniedbania

6 Por. F. Znaniecki, Socjologia wychowania, t. 1, Wychowujące społeczeństwo, Warszawa 2001, s. 3. 
w zakresie uspołecznienia ${ }^{7}$, to podmiotowy, sprawczy i zindywidualizowany wkład i udział osoby wychowywanej w procesie jej socjalizacji nie jest raczej kwestionowany (nie ma się na myśli siermiężnych i wykrzywionych modeli wychowawczo-socjalizacyjnych społeczeństwa $\mathrm{z}$ dominacją dyktatury i totalitaryzmu).

Istotnym elementem przebiegu procesów wychowawczo-rozwojowych jest ukontekstowienie. Byłoby zaprzeczeniem podmiotowości i wolności zarówno sprawców wychowania, jak i tych, którzy są mu poddawani, gdyby założyć, że kontekst całkowicie determinuje zarówno przebieg, jak i mechanizmy wychowawczo-socjalizacyjne. Jednak wpływ ten jest znaczący, choć nie decydujący. Procesy wychowawcze, edukacyjne i socjalizacyjne, których adresatami są konkretne jednostki, wywierają wpływ na ich biografie. Jan Szczepański nazwał ten proces uwewnętrznianiem społeczeństwa $\mathrm{w}$ jednostkach $^{8}$. Można by przyjąć deterministyczny pogląd, iż uwewnętrznienie dokonuje się z wszystkimi konsekwencjami, to znaczy z balastem tego, co dobre, i tego, co w społeczeństwie złe. Jednak czy zawsze oddziaływanie społeczeństwa złego (zamkniętego) przeniesie te cechy na jednostkę? Czy $\mathrm{z}$ kolei zdrowe, poprawnie funkcjonujące społeczeństwo wywrze li tylko pozytywne skutki na biografii jednostkowej?

Gdyby forsować ów prosty mechanizm - w jakimś sensie logiczny - lansowałoby się dość mechanicystyczną wizję człowieka oraz zbyt uproszczony schemat wychowania i socjalizacji. Ostatecznym efektem końcowym (jeśli można konstatować o skończonej wychowawczo postaci wychowanka) jest gra pomiędzy tym, co jest siłą społeczeństwa i podmiotowością jednostki. Czysto konformistyczna wizja człowieka daleka jest od ideału socjalizacyjnego. Znaniecki podkreślał siłę oddziaływania procesów wychowawczych na ich udział w życiu wspólnoty, zbiorowości, w której się znajdują i do której przynależą. Jest to doświadczenie w pewnym sensie uniwersalne, a badania prowadzone w obrębie choćby socjologii wychowania ukazują obraz swoistej konwergencji i podobieństwa struktury tych procesów, efektów, które w jego wyniku powstająa.

Podłoże genetyczne procesów wychowawczych wyłania się jako odsłona jakiegoś fundamentalnego gruntu skłonności jednostkowych, niezależnie

7 Zob. B. Śliwerski, Diagnoza uspołecznienia publicznego szkolnictwa III RP w gorsecie centralizmu, Kraków 2013.

8 Por. J. Szczepański, Elementarne pojęcia socjologii, Warszawa 1972, s. 127.

9 Por. F. Znaniecki, Ludzie teraźniejszości a cywilizacja przyszłości, Warszawa 2001, s. 2. 
142 od czasu i przestrzeni, w której się one dokonują. Maturacjonizm linearno-cykliczny w tym sensie będzie sugerował wartość odnoszenia się do jakiegoś wspólnego fundamentu, który jest zwornikiem i kanałem gwarancji poprawności prowadzonych mechanizmów edukacyjno-wychowawczych.

\subsection{Socjalizacja i wychowanie jako odtwarzanie, powtarzanie i łączenie}

Rzeczywistość wychowawcza jest „powtarzalnością? i „odtwarzalnością” społecznego ukonstytuowania. Anthony Giddens rozwinie tę tezę w pojęciu tzw. teorii strukturacji ${ }^{10}$. Odtwarzanie struktury wychowawczo-socjalizacyjnej jest ukierunkowane na przyszłość, co wszak jest zasadniczym elementem bytowania człowieka w ogóle - ma się na uwadze przede wszystkim jego codzienność. Powtarzalność - zawarta głównie w cykliczności - jest warunkiem skutecznego przekonywania (perswadowanie w wychowywaniu i socjalizowaniu stanowi jedną z ważniejszych technik oddziaływania na wychowanka). Lecz powtarzalność, odtwarzalność i powracanie do mechanizmów przywoływania duchów z przeszłości to przede wszystkim wyławianie i poszukiwanie cennych, ponadczasowo skutecznych metod oraz instrumentów wychowawczych. Jest to ponadto sięganie do wciąż niezrealizowanych ideałów, z przekonaniem, iż w nowych okolicznościach i przy większym dziejowym doświadczeniu mogłoby to się w końcu dokonać. Wiara w ideały społeczne, ludzkie, lecz także w dobór coraz doskonalszych (idealnych) metod wychowawczo-socjalizacyjnych, jest żywotną siłą, ponieważ instytucje wychowawcze reprezentowane przez konkretne podmioty dostrzegają nowe możliwości (sukcesy wychowawcze) w przyszłości. Andrzej Radziwicz-Winnicki stwierdza: „Codzienność jednak wybiega z reguły w przyszłość, wiąże powinności dnia dzisiejszego z celami pozostającymi do osiągnięcia w dniu jutrzejszym"11.

Nie tylko rzeczywiste biografie jednostkowe oraz historie grup społecznych mogą zawierać w sobie siłę treści będących połączeniem tego, co minęło,

10 „Zgodnie z nią głównym przedmiotem badań nauk społecznych nie jest ani doświadczenie indywidualnego aktora, ani jakakolwiek całość społeczna, lecz uporządkowane w czasie i przestrzeni praktyki społeczne. Ludzkie czynności społeczne, tak jak niektóre samoreprodukujące się obiekty przyrody, są powtarzalne. Znaczy to, że aktorzy społeczni nie tworzą ich, lecz je stale odtwarzają za pośrednictwem środków właściwych sobie jako aktorom", A. Giddens, Stanowienie społeczeństwa. Zarys teorii strukturacji, przeł. S. Amsterdamski, Poznań 2003, s. 40.

11 A. Radziewicz-Winnicki, Społeczeństwo w trakcie zmiany, Gdańsk 2005, s. 9. 
z tym, co jest teraz, oraz z tym, co może dopiero nastąpić. Posłużmy się przy-

kładem z klasyki myśli filozoficzno-społecznej. Platon zastanawiał się nad wartością tworzenia opowieści, mitów, narracji, które miałyby potencjał sprawczy i socjalizacyjny w odniesieniu do jednostek, zwłaszcza młodocianych. Dialog pomiędzy bohaterami Państwa wskazuje na niejednoznaczność interpretacyjną w kwestii wartości tychże treści. Najpierw: „To słuchającym bardziej szkodzi. Bo każdy będzie miał wybaczenie dla własnych złych stron, przekonany, że przecież to samo robią i robili. [...] Dlatego dać pokój takim mitom, aby nam u młodzieży nie zaszczepiały lekkiego rozgrzeszenia dla wad charakteru"12.

Przeszłość - skoro się opowiada o pewnych faktach, to dlatego, że miały już one miejsce - mimo że przeminęła, jest żywa i może dwojako wpływać na osobowość jednostek. Nawet jeśli opiera się o wyimaginowaną fabułę, to w jakimś sensie jest ona efektem czegoś, co miało miejsce i co posłużyło za inspirację do stworzenia tejże fabuły. Nakładać się może na nią także jakaś idea, która została wymyślona i wobec której przyjmuje się postawę wiary w jej realizowalność. W myśli Platona opis zachowań wymyślonych bohaterów, których postępowanie należałoby napiętnować ze względu na jego negatywne reperkusje, wynika z silnego oddziaływania i potencjalnego nakłaniania do niegodziwego życia. Oceniając krytycznie stanowisko platońskie, można przyjąć, że negatywne charakterystyki - odpowiednio zinterpretowane przez wychowawców i dydaktyków - mogą być asumptem do postawy zupełnie przeciwnej, czyli pożądanej, właściwej. Platon odsłania jednak logikę maturacjonizmu linearno-cyklicznego: „Czy nie wszystko, cokolwiek mówią twórcy mitów i poeci, jest opowiadaniem tego, co się stało, co jest, albo tego, co ma być kiedyś?"13. Rzeczywistość, w której dokonują się relacyjne procesy maturacjonizmu pomiędzy wychowankami, wychowawcami, oraz świat wyimaginowanych idei, fikcji, fabuł, w które wplecione są w jakimś sensie i za każdym razem losy człowieka, mają jakieś wspólne podłoże genetyczne.

\subsection{Aksjonormatywna wartość podłoża genetycznego w procesach maturacjonizmu linearno-cyklicznego}

Podstawa genetyczna wydaje się wystarczająco zasadna, by na niej oprzeć inicjację i przebieg procesu maturacjonizmu linearno-cyklicznego w obszarze

12 Platon, Państwo, przeł. W. Witwicki, Kęty 2003, s. 88.

13 Platon, Państwo, dz. cyt., s. 89. 
144 wychowania. Więź i konsolidacja genetyczna członków społeczeństwa konstytuuje się jako społeczna natura. Także odwrotnie: społeczna natura może stanowić grunt genetyczny dla relacyjnego i metamorficznego kształtowania bytu jednostkowego. Arystoteles ujął to niezwykle trafnie: „Kto zaś nie potrafi żyć we wspólnocie albo jej wcale nie potrzebuje, będąc samowystarczalnym, bynajmniej nie jest członem państwa, a zatem jest albo zwierzęciem, albo bogiem. Wszystkim ludziom właściwy jest $\mathrm{z}$ natury pęd do życia we wspólnocie, a ten, kto ją pierwszy zestroił, jest twórcą największych dóbr. Jak bowiem człowiek doskonale rozwinięty jest najprzedniejszym ze stworzeń, tak jest i najgorszym ze wszystkich, jeśli się wyłamie z prawa i sprawiedliwości. Najgorsza jest bowiem nieprawość uzbrojona, człowiek zaś rodzi się wyposażony w broń, jaką są jego zdolności umysłowe i moralne, które, jak żadne inne, mogą być niewłaściwie nadużywane. Dlatego człowiek bez poczucia moralnego jest najniegodziwszym i najdzikszym stworzeniem, najpodlejszym w pożądliwości zmysłowej i żarłoczności. Sprawiedliwość zaś jest znamieniem państwa, wymiar jej jest bowiem podstawą porządku istniejącego we wspólnocie państwowej, polega zaś na ustalaniu tego, co jest sprawiedliwe"14.

Proces „włączania” własnych, sprawczych, indywidualnych cnót do wartości przekazywanych jest w jakimś sensie ciągły, kierunkowy, kumulatywny, a należy to rozumieć jako kontynuowanie pewnej płaszczyzny genetycznej rodzaju ludzkiego. Można myśleć o czymś wspólnym, jednym, zintegrowanym. W myśli socjologicznej wielokrotnie było to wyrażane metaforycznie, z lepszym lub gorszym skutkiem i rodzajem egzemplifikacyjno-dowodowym. Organizm, system, jedność, sieć indywiduów, byt relacyjny, struktura - takie obrazy sugerują sumowanie jednostkowe, ale i integralność podmiotowych bytów, zespolonych dla jakiegoś celu. W trakcie przebiegu procesu wychowawczego czy socjalizacyjnego podmioty realizujące swoją aktywność raczej nie kierują się bezpośrednio myślą, by którąś z tych postaci zrealizować. Są bardziej ukierunkowane na konkretny „obiekt” działania, na osiąganie tego, na czym im najbardziej przecież zależ ${ }^{15}$, w zgodzie $\mathrm{z}$ własnym programem, czymś, co Stefano Bartolini wyraził w tytule swej publikacji Manifesto per la felicità ${ }^{16}$.

14 Arystoteles, Polityka, przeł. L. Piotrowicz, Warszawa 2004, s. 28.

15 F. Znaniecki, Znaczenie rozwoju świata i człowieka, przeł. J. Szacki, [w:] J. Szacki, Znaniecki, Warszawa 1986, s. 198-199.

16 Zob. S. Bartolini, Manifesto per la felicità. Come passare dalla società del ben-avere a quella del ben-essere, Milano 2013. 
Szczególną subdyscypliną socjologii jest ta, która swoim spojrzeniem

badawczym diagnozuje edukację i wychowanie. Pierre Bourdieu oraz Jean-Claude Passeron w Reprodukcji - klasycznym dziele w tym obszarze socjologicznym rozwijają myśl o tym, iż model rozwoju - również ten wykorzystywany w obszarach edukacji - opierający się na technokratycznym wzorze linearności i jednowymiarowości, występujący rzekomo w fazach historycznych przeobrażeń, jest wyjątkowo uproszczony ${ }^{17}$. Cykliczność nie jest jedynie aneksem koncepcyjnym. Stanowi bowiem niezbędne i rzeczywiste dopełnienie prostej i stadialnie ukierunkowanej idei. Kontynuacja w swojej najprostszej formie może być przecież nie tylko zachowywaniem czy zwykłym przedłużeniem status quo. Może także instytucjonalizować błędne, zacofane i skostniałe struktury przyzwyczajeń. Może promować zacieśnione wizje odnoszące się do własnego i innych życia. Ponadto może doszukiwać się sensu w małostkowych i zawężonych wyobrażeniach odnoszących się do człowieka i świata.

Kontynuacja może ograniczać i hamować proces rzeczywistego otwarcia na dobra cywilizacyjne, dla których nie bez znaczenia są procesy socjalizacyjne i wychowawcze. Warto przypomnieć, iż kształcenie i formacja w czasach prymitywnych miały charakter kontynuacyjny. Dokonywało się to pomiędzy pokoleniami rodziców i dzieci. Czasy nowoczesne, z rozwiniętym systemem edukacyjnym są zerwaniem owej kontynuacji, niejako na zasadzie wyciągania pokolenia dzieci z matni analfabetyzmu, w którym tkwili ich rodzice. Dzieci stają się odmiennym pokoleniem wykształconych i umiejących pisać i czytać, w przeciwieństwie do tych, którzy tego nie potrafią. Ten wyłom i przełom nie jest przecież niemoralny z tego powodu, iż nie stanowi kontynuacji międzypokoleniowej ${ }^{18}$. W tej kwestii cykliczność niejako ustępuje miejsca linearności, jednak jedynie w działaniu prostego mechanizmu postępu, jego wymogów.

Gdy kładzie się nacisk na rodzaj „materii”, która wykorzystywana jest w procesach socjalizacji oraz w dążeniach maturacjonistycznych, najczęściej ma się na uwadze pewien zasób duchowy, kulturowy, aksjonormatywny, który jest niezbędny do uruchomienia rzeczonych procesów. Jednak nie tylko sfera społeczna, ale i stricte materialna kształtują osobowość, wywołują konkretne i specyficzne zachowania społeczne. Można posłużyć się przykładem

17 Por. P. Bourdieu, J. C. Passeron, Reprodukcja. Elementy teorii sytemu nauczania, przeł. E. Najman, Warszawa 2012, s. 280-281.

18 Por. A. Bagnasco, M. Barbagli, A. Cavalli, Sociologia. II. Differenziazione e riproduzione sociale, Bologna 1997, s. 202. 
146 z zakresu socjologii przestrzeni. Niezwykle silne oddziaływanie przestrzeni miejskiej na jej mieszkańca to przykład rodzaju materialnego surowca socjalizacyjnego. Przestrzeń miejska jest w stanie sugestywnie przekazywać nam to, co ze względu na doświadczenia z przeszłości kryje w sobie. Przestrzeń tak rozumiana może być porównana do domu rozumianego jako kontekst relacji, wspólnota doświadczeń, przeżyć, wyznawanych wartości, dzielonych pomiędzy jej mieszkańcami praktyk i przekonań. Jest to możliwe dzięki jego usytuowaniu w historii - narracja historyczno-aksjonormatywna ${ }^{19}$.

Przywoływanie przez młodsze pokolenie i uznawanie jako wartościowych doświadczeń pokolenia starszego, które chętnie dzieli się z młodszym owym bogactwem (zinternalizowanym splotem historyczno-biograficznym), może stanowić linearno-cykliczną odsłonę socjalizacyjną, dodatkowo zintegrowaną międzypokoleniowo. Tak specyficznie uruchomiony proces oddziaływania przestrzeni - w tym przypadku przestrzeni miejskiej - sprzęga w sobie i uruchamia maturacjonizm grupy i jednostki. Sięganie do historii wpisanej w przestrzeń (będącą ujarzmionym komunikatorem jakiegoś kodu treściowo-wartościującego ${ }^{20}$ ) oraz nadawanie jej nie tyle nowego znaczenia, ile nowej interpretacji przeżyciowej, odzwierciedla spiralną ideę rozwoju i formacji, co jest możliwe dzięki wspólnocie podłoża genetycznego, na którym nadbudowana jest siła przestrzeni i wrażliwość jej percepcji.

\section{Socjalizacja, niepełnosprawność, uczelnie wyższe - refleksyjność relacyjna maturacjonizmu}

Kategoria maturacjonizmu linearno-cyklicznego może się zawierać w obszarach socjalizacyjno-wychowawczych nie tylko koncepcyjnie i nie jedynie jako pewien zarys interpretacyjny. Stanowi rodzaj komponentu, który może rzeczywiście konstytuować bieg i dynamikę procesu wychowawczego. Procesy rozwojowe, które przebiegają w środowisku wychowawczym, w relacjach wychowawczych, w oddziaływaniach podmiotów socjalizacyjnych, dokonują się w kontekście i w obszarze swego rodzaju sprzężeniu. Jest ono zawarte w linearności, która stanowi wymóg tegoż rozwoju, konieczność

19 Por. M. Botta, P. Crepet, G. Zois, Dove abitano le emozioni. La felicità e i luoghi in cui viviamo, Trento 2007, s. 5.

20 Por. P. Prüfer, Gdzie „zamieszkuja” emocje? Odczuwanie, przeżywanie i doświadczanie przestrzeni miejskiej, [w:] Lublin 2020. Cztery oblicza przyszłości miasta, pod red. M. Sagana, K. Żuka, Lublin 2014, s. 38. 
cywilizacyjną, wyzwanie-warunek oddziaływań i oczekiwań społecznych. Jest też cykliczne, ponieważ w dziedzinie wychowania - jeśli ma być realizacją wspomnianych oczekiwań - bazuje na wypracowanych i sprawdzonych od dawna ideach (niekoniecznie i dosłownie metodach - te mogą być wciąż zmienne). Maturacjonizm tak rozumiany i odniesiony do wychowawczo-socjalizacyjnego kontekstu przebiega w zespoleniu tego, co jest intencjonalnie realizowaną czynnością formacyjną, z tym, co byłoby indywidualnym (podmiotowym) wzbogacaniem siebie i innych. To ostatnie dokonywałoby się poprzez samowychowanie i ukierunkowaną na własny proces rozwojowy refleksyjność, która z natury swej jest relacyjna, niezależnie czy rozumiemy Alter jako ja czy Alter jako inny ${ }^{21}$.

W procesach linearno-cyklicznych ukryta jest zarówno idea ciągłości, następowania po sobie kolejnych stadiów rozwojowych, które w socjalizacji dokonują się nie tylko w praxis jako takiej, lecz w przemyślanym - intencjonalnym zaangażowaniu twórczym oraz w świadomości doskonalenia tego procesu. U jednostki coraz bardziej socjalizowanej następuje proces przyrostu percepcji rozumienia konieczności liczenia się z innymi. Dokonuje się to wraz z zaawansowaniem chronologicznym etapu swojego życia. Innymi słowy, im więcej socjalizacji dokonywanej w czasie, tym większa świadomość, że kontekst społeczny (inni) ma wpływ na życie podmiotu. Socjalizacja to proces pozwalający jednostce stać się homo socius. Uspołecznienie jest możliwe także dlatego, że jednostka internalizuje przekonanie o konieczności budowania projektów na przyszłość. Taka perspektywa „zagarnia” koncepcyjnie ślady przeszłości. Dokonuje diagnozy teraźniejszości. Jest tym samym linearno-cyklicznym kreśleniem i łączeniem celowości aktywności wychowawczo-socjalizacyjnej lokującej się w jakimś sensie ponadczasowo.

Jednostka uświadamia sobie, że ma być socjalizowana bez konieczności legitymizowania, dlaczego tak się powinno dziać. Sam fakt socjalizowania usprawiedliwia ten trud. Socjalizacja linearno-cykliczna i ponadczasowa, powiązana z maturacjonizmem jednostkowo-społecznym, jest istotnie skorelowana $z$ działaniem pedagogicznym. Znajduje więc swoje dopełnienie i uzupełnienie w wychowaniu. Zarys idei zakorzenia się także na zmaganiach teoretyczno-praktycznych lokujących się w obrębie pedagogiki. Ta z kolei jako nauka o wychowaniu jest dyscypliną naukową i jako taka stanowi spore wyzwanie metodologiczne i konceptualizacyjne dla zainteresowanych jej

21 Por. P. Donati, Sociologia della riflessività. Come si entra nel dopo-moderno, Bologna 2011, s. 77-79. 
148 uprawianiem. Ich osiągnięcia są jednak bezcenne dla innych badaczy, w tym także dla socjologów. Jednym z najważniejszych osiągnięć i jednoczenie pomostów pomiędzy pedagogiką i socjologią jest to, że wybitni przedstawiciele nauk o wychowaniu dostrzegają konieczność, a przynajmniej korzyści płynące z jej „urefleksyjnienia”. Bogusław Śliwerski, ważna postać dla myśli pedagogicznej, zwłaszcza polskiej, z przekonaniem stwierdza: „O sile pedagogiki jako dyscypliny naukowej świadczy to, że refleksyjnie, z wielkim dystansem i powagą racji wchłania nowości pojawiające się w naukach społecznych i humanistycznych, reagując niemalże natychmiast na zmiany społeczno-polityczne w społeczeństwach nam współczesnych i stawiając czoła ich wyzwaniom czy nadziejom" 22 .

Procesy socjalizacyjne związane $\mathrm{z}$ ujęciem maturacjonistycznym w odniesieniu do społeczeństwa i jednostki formowanej przez różne społeczne czynniki wyłaniają się ze szczególną wyrazistością, gdy jednak zastosuje się przede wszystkim narzędzia socjologiczne. Mechanizmy socjalizacyjne (jak już wielokrotnie zostało zasygnalizowane - charakteryzujące się linearno-cyklicznymi technikami ich stosowania) przebiegają na kilku poziomach. Najpierw jest to poziom najbardziej ogólny, w którym ma miejsce zdobywanie kompetencji niezbędnych dla społecznej egzystencji, czyli czas i przestrzeń, w których jednostka opanowuje minimum kulturowe, co jest jakimś uniwersalnym wymogiem każdego człowieka. Kolejny poziom dotyczy przyswojenia konkretnej kultury. Etap trzeci to ostatecznie przestrzeń, w której jednostka zostaje uzdolniona do opanowania i realizacji konkretnych ról społecznych. Jest to więc proces wielopoziomowy i wielopłaszczyznowy ${ }^{23}$.

Za każdym razem wiąże się z trudem retrospektywnego (cykliczność) i perspektywicznego (linearność) drążenia osobowości jednostki, wyposażając ją w niezbędne kompetencje społeczne (maturacjonizm jednostkowy). Nie wydaje się, aby przez to socjalizacja - na jakimkolwiek poziomie - mogła być procesem skończonym albo przebiegającym jednokierunkowo. Nawet wtedy, gdy jego trajektorie są wielostronne, skomplikowane, zawiłe i wyrafinowane, cykliczność tego systemu sekwencji socjalizacyjnej wyłania się jako logiczna, uzasadniona i niezbędna. Wtedy można z uzasadnieniem mówić o rzeczywistej socjalizacji. Taka jej postać znajduje swoje teoretyczne ulokowanie w koncepcji maturacjonizmu linearno-cyklicznego.

22 B. Śliwerski, Wprowadzenie, [w:] Pedagogika, t. 1, Podstawy nauk o wychowaniu, Gdańsk 2006, s. VII.

23 Por. P. Sztompka, Socjologia. Analiza społeczeństwa, dz. cyt., s. 450-451. 
Zakładając, że jakiś badacz społeczny zaczyna ukierunkowywać swoje poszukiwania intelektualne na problematykę niepełnosprawności, nie sięgając do danych uzyskanych w przeszłości w odniesieniu do tej problematyki, powoduje on spore zaciemnienie $w$ diagnozowaniu tego, co i jak jest teraz. Najprawdopodobniej stwierdzi - już po pobieżnych kwerendach i przeglądach dokonanych w odniesieniu do obecnego aktualnego piśmiennictwa - że stan wiedzy jest rzeczywiście znaczący, i - co ważne - odkrywczy, nierzadko wybiegający w przyszłość (teoria wyprzedza praktykę). Ma jednak świadomość linearno-cykliczną, która pobudza go do zastosowania tejże metody poznania, by mieć pełniejszą świadomość i perspektywę badawczą, nawet jeśli w tej dziedzinie zdecydowanie istotniejsze zdają się nowe rozwiązania teoretyczne. Jednak byłby pozbawiony ważnej świadomości tego, jak w tym obszarze badań dokonał się zadziwiający progres. Wystarczy zatrzymać się przy socjologicznym ujęciu kwestii niepełnosprawności.

Rozpocznijmy od nakreślenia najpierw „łagodniejszej” wersji dziedzictwa socjologicznego. Otóż początki socjologicznej refleksji w tej dziedzinie związane są z analizą teorii ról społecznych. Samo pojęcie „roli społecznej” zapożyczone zostało z literatury i dramatu. Oznaczałoby to postawę odgrywania pewnej roli np. w teatrze, co jest zasadniczą aktywnością konkretnego aktora. Sposób odgrywania tej roli może być np. dynamiczny. Można w nim widzieć cały szereg strategii interakcyjnych (z którymi zwłaszcza w interakcjonizmie symbolicznym utożsamiano rolę społeczną). Te z kolei byłyby nieobojętne normatywnie ${ }^{24}$. Podobnie jak osoby w pełni sprawne i mające pełny dostęp do wszelkich dóbr społecznych, tak osoby z niepełnosprawnością mogą wypełniać swoiste role w społeczeństwie. Podobnie rzecz się ma w przypadku chorego, który także wypełni swoją specyficzną rolę - na co wskazywali niektórzy $\mathrm{z}$ wybitnych socjologów teoretyków, np. Talcott Parsons ${ }^{25}$ - również osoby $z$ dysfunkcjami psychofizycznymi mogą realizować ten rodzaj funkcji społecznej. Postrzegać jednak obecność osób z niepełnosprawnościami, ukazując je jako podmioty wykonujące swoje role - czy nie to będzie zbyt daleko idącym uproszczeniem i normatywnym uchybieniem? Czy nie będzie to ukierunkowanie zdecydowanie ambiwalentne normatywnie? Swoista dwuznaczność i odmienność działania niektórych elementów świata społecznego na jednostkę istniała od zawsze, od kiedy istniało społeczeństwo. Jak

24 Por. J. Szmatka, Rola społeczna, [w:] Encyklopedia socjologii, pod red. W. Kwaśniewicza i in., t. 3: O-R, Warszawa 2000, s. 322.

25 Zob. T. Parsons, System społeczny, przeł. M. Kaczmarczyk, Kraków 2010, s. 319-355. 
150 zazwyczaj pozytywnie rozumiana kultura może jednak ambiwalentnie kształtować dobrostan jednostki (włącznie z wpływem tejże kultury na jej zdro$\left.w_{i}{ }^{26}\right)$, tak kwestia odgrywania ról społecznych może być zarówno czymś pozytywnym, jak i negatywnym. Taka dwuznaczność powinna być wyeksponowana, by tym samym nie ograniczać się arbitralnie do jednej z nich.

Wydaje się, że opcja ta jest nie tylko ograniczona, ale niewiele ma wspólnego z podmiotowym rozumieniem osoby (jakiejkolwiek). Taka perspektywa jest raczej podszyta pozornym uwrażliwieniem typu: należy wdrożyć osoby z niepełnosprawnościami do funkcjonującego systemu społecznego. Warto dodać, iż pierwsze zainteresowanie problematyką niepełnosprawności w socjologii wiązało się z naciskiem ze strony instytucji medycznych. Nawet jeśli wiązało się to z próbami ulepszania metod terapeutycznych ${ }^{27}$, cel i rozwiązanie problemu tkwią w punkcie wyjścia. Konieczna wydaje się zmiana perspektywy, krok naprzód, linearny wymóg rozwojowy i maturacjonistyczny.

Jeszcze bardziej wątpliwie normatywnie i badawczo przedstawia się problematyka badań nad niepełnosprawnością w latach sześćdziesiątych. Eliot Freidson oraz Fred Davis interpretowali niepełnosprawność i kalectwo w terminologii, która dziś wyjątkowo nie może być zaakceptowana. Przekonywali, że niepełnosprawność należy łączyć z teorią dewiacji społecznej lub naznaczenia społecznego. Było to nawiązanie do Ervinga Goffmana, Howarda Beckera i Edwina Lemerta. Koncepcje teoretyczne miały być wykorzystywane dla potrzeb praktyki. Warto zauważyć, iż pojęcie dewiacji społecznej wskazuje na jakiegoś rodzaju odchylenie od normy, zejście z powszechnie uznawanej za prawidłową drogi. W takiej sytuacji może być kojarzone z jeszcze innymi wątpliwymi określeniami, takimi choćby jak „patologia” czy „dezorganizacja społeczna”. Budowany był zatem pejoratywny repertuar pojęć, który w zestawieniu z problemem niepełnosprawności poszerzał i pogłębiał i tak dramatyczny i pesymistyczny obraz. Socjologia rozpatruje dewiację jako dezintegrację, zachowanie wyuczone bądź nabyte, które niejako automatycznie włącza w obieg naznaczenia społecznego ${ }^{28}$.

Wspomniany okres zainteresowań socjologicznych niepełnosprawnością cechuje także perspektywa, w której rozpatruje się ją na podobieństwo

26 Por. E. Jaroszewska, Kultura jako czynnik warunkujący zdrowie, diagnozowanie chorób i ich leczenie, „Problemy Polityki Społecznej” 21 (2013) 2, s. 72.

27 Por. A. Ostrowska, Niepełnosprawność, [w:] Encyklopedia socjologii, pod red. W. Kwaśniewicza i in., t. 2: K-N, Warszawa 1999, s. 334.

28 Por. J. Kwaśniewski, Dewiacja społeczna, [w:] Encyklopedia socjologii, pod red. W. Kwaśniewicza i in., t. 1: A-J, Warszawa 1998, s. 125-129. 
przynależności do grup mniejszościowych (takich jak niektóre małe grupy religijne czy etniczne ${ }^{29}$. Krytyczne spojrzenie na retrospektywny obraz badań nad niepełnosprawnością w tym przypadku jest jednak istotne, by cykliczność mogła wyłonić konieczność zastępowalności pewnych nieadekwatnych ujęć takimi, które z racji choćby podmiotowości i waloryzacji jednostkowej powinny znaleźć zupełnie inny (przeciwny) klucz hermeneutyczny.

Uczelnie wyższe i obecne na nich osoby z niepełnosprawnościami (ujęcie aktualne) są wyjątkowo dobrze skorelowanym problemem, który oczywiście ma wiele nieakceptowanych i dziś aporii, lecz tworzy zupełnie inną perspektywę. Wydaje się ona szczególnie rozwojowa (linearno-cykliczna; maturacjonizm in moto). Struktury edukacyjne na poziomie uczelnianym są w jakimś sensie odzwierciedleniem idei universitas, a więc tej, która konstytuuje samą istotę tejże instytucji. Obejmuje zatem cały repertuar czynników, kontekstów, idei, ale przede wszystkim osób, dla których je powołano i stworzono. Cenną realizacją tej idei jest fakt, że z powodu naturalnie powstałych przeszkód dla wielu potencjalnych i pozostających w uczelnianej cyrkulacji osób, stwarza się, zwłaszcza ostatnio, wręcz rewolucyjne możliwości, by mogła się realizować idea universitas. Ma się tutaj na myśli przede wszystkim osoby z niepełnosprawnościami, które w rzeczywistości uczelnianej takimi pozostają, pomimo zaangażowanych czynników wspierających.

Osoby $\mathrm{z}$ niepełnosprawnościami z powodu jakiegoś wydarzenia lub wydarzeń patogennych doznały pewnego braku (całkowitego lub częściowego pozbawienia integralności struktury lub funkcji anatomicznych, fizycznych lub psychicznych). Mowa tu o sytuacji nie-sprawności, redukcji lub w jakimś zakresie - absencji zdolności, niezbędnych do realizacji własnej osobowości w granicach uznawanych za normalne, zwyczajne w życiu człowieka ${ }^{30}$. Idea universitas zawiera w sobie cenną wartość komplementarności, która wyraża się choćby w zdolności do „uzupełniania” braków, zbliżania odmienności, łączenia różnic, które nie są niepokonalne. Można by stwierdzić, iż odmienność, różnorodność i braki (z racji niepełnosprawności) nie są na uczelni rzeczywistymi brakami. Są okazją do „wymieszania” różnorodności, która konstytuuje i wzmacnia byt uczelniany.

Procesy maturacjonistyczne - linearno-cykliczne dojrzewanie instytucjonalno-społeczne - mogą być wciąż dynamicznym procesem przyrostu tej

29 Zob. C. Safilios Rothschild, The sociology and social psychology of disability and rehabilitation, New York 1970.

30 Por. G. Scotti, Disabili, [w:] Dizionario di dottrina sociale della Chiesa. Scienze sociali e Magistero, a cura di L. Ornaghi, Milano 2004, s. 261. 
152 świadomości. Można przytoczyć fragment dokumentu papieża Franciszka (choć nie odnosi się on do niepełnosprawności ani do uczelni wyższych; nie jest także socjologiczny, lecz teologiczny), który nie tylko egzemplifikuje, lecz przede wszystkim wyjaśnia bogactwo takiego „wymieszania”, w którym nie chaos stanowi efekt końcowy, lecz dojrzała integracja i komplementarność: „Dzisiaj, gdy sieci i narzędzia komunikacji ludzkiej osiągnęły niesłychany rozwój, stajemy przed wyzwaniem, by odkryć i przekazać «mistykę» życia razem, wymieszania się, spotkania, wzięcia za rękę, wzajemnego oparcia, uczestnictwa w tej nieco chaotycznej masie, która może zamienić się w prawdziwe doświadczenie braterstwa, w solidną karawanę, w święte pielgrzymowanie. $\mathrm{W}$ ten sposób większe możliwości komunikacji zamienią się w większe możliwości spotkania i solidarności między wszystkimi. Gdybyśmy mogli iść tą drogą, byłoby to rzeczą tak dobrą, tak uzdrawiającą, tak wyzwalającą, tak bardzo rodzącą nadzieję!"31.

\section{Zakończenie}

Maturacjonizm to idea, w kontekście której można spojrzeć na dojrzewanie i rozwój społeczeństwa oraz jednostki. Pojęcie to jest uzupełniane i wyjaśniane dwoma istotnymi intuicjami: cyklicznością i linearnością. W przedłożonych analizach poszukiwano różnych dróg eksplikacji tej idei, w szczególny sposób odnosząc je do kontekstów edukacyjno-socjalizacyjnych, szczególnie związanych z niepełnosprawnością. Cały szereg przedsięwzięć mających na celu kontynuację procesów rozwojowych w obszarach edukacyjnych domaga się powiązania dwóch wymiarów rzeczywistości (linearnej i cyklicznej), umożliwiającej rzeczywiste dojrzewanie integralne i wielopłaszczyznowe społeczeństwa i jednostek. Kwestia niepełnosprawności jest zarówno osobliwym tego przykładem, jak i wciąż nowym wyzwaniem do realizacji. Ewolucja myśli badawczej - zwłaszcza socjologicznej, a odnoszącej się do niepełnosprawności i jej obecności na uczelni wyższej - jest widoczna, lecz wciąż ma swoje aporie, nie zawsze wynikające ze zrozumiałych przyczyn. Próba wiązania dobrych praktyk i osiągnięć, która dokonała się w minionym czasie, nie może uśpić zadowolonych umysłów, gdyż każda taka skłonność przyczynia się do erozji i zahamowania biegu dalszych procesów rozwojowych. Mądre i perspektywiczne kształtowanie poglądu o dokonywaniu się „procesów wzrostu” 
poprzez możliwości nieantagonistycznego sprzężenia sprawczości jednost-

kowej z determinacją strukturalną społeczeństwa wspierają idee maturacjonizmu. Nie wydaje się, aby obszary uczelniane oraz aktywności mające na celu zintegrowanie niepełnosprawności z całym środowiskiem akademickim mogły obwieścić sukces w tym zakresie. Jest wiele do zrobienia, tym bardziej że nie brakuje mechanizmów i instrumentów wspierających realizację takich procesów. Do takich wniosków można dojść jedynie w pewnym tylko i wąskim zakresie, choćby dlatego, że droga do nich jest tylko skromną i socjologiczną teoretycznie analizą. Stanowisko socjologa i jego praca zawsze w jakimś sensie domagają się uzasadnienia nie tylko przedmiotu prowadzonego dyskursu, ale własnej tożsamości badacza społecznego. Można powtórzyć za Pierreem Bourdieu: „To dziwne, że jeżeli socjolog z takim trudem zdobywa poczucie, że jego istnienie jest uzasadnione, to dlatego, że oczekuje się od niego albo za dużo, albo za mało"32.

Linear and cyclic processes of formation and socialization in the society and in the academic environment and disability

The present day reflects the effect of impact of the new, with what is inherited from past generations. This includes the various spheres of social life, including science, located in the areas of institutional (university). The presence of universities persons with disabilities is largely positive effect of connecting the past with the present, and build on this principle mature individual-social consciousness. Revival of the basic ("finite"), the principles and values of human life and the emergence of new and modern elements conducive to the development, part and institutional maturation condition the unit, which can confirm the broader context of a maturing society as a whole.

Keywords: disability, academic environment, development

\section{Linearne i cykliczne procesy formacyjno-socjalizacyjne w społeczeństwie i w środowisku akademickim a niepełnosprawność}

Dzisiejszy świat ukazuje efekt oddziaływania tego, co nowe, z tym, co jest dziedziczone w poprzednich pokoleniach. Dotyczy to różnych sfer życia społecznego, w tym

32 P. Bourdieu, Pochwała socjologii, przeł. M. Ziółkowski, „Kultura i Społeczeństwo” 57 (2013) 1, s. 8. 
154 nauki w obszarze instytucjonalnym (uniwersytet). Obecność osób niepełnosprawnych w uczelni jest w dużej mierze pozytywnym efektem połączenia przeszłości z teraźniejszością i budowania w tym kontekście dojrzałej indywidualno-społecznej świadomości. Pojawienie się nowych i nowoczesnych elementów sprzyjających rozwojowi może potwierdzić szerszy kontekst dojrzewania społeczeństwa jako całości.

Słowa kluczowe: niepełnosprawność, środowisko akademickie, rozwój

\section{Bibliografia}

Archer M. S., Człowieczeństwo. Problem sprawstwa, przeł. A. Dziuban, Kraków 2013. Arystoteles, Polityka, przeł. L. Piotrowicz, Warszawa 2004.

Bagnasco A., Barbagli M., Cavalli A., Sociologia. II. Differenziazione e riproduzione sociale, Bologna 1997.

Bartolini S., Manifesto per la felicità. Come passare dalla società del ben-avere a quella del ben-essere, Milano 2013.

Botta M., Crepet P., Zois G., Dove abitano le emozioni. La felicità e i luoghi in cui viviamo, Trento 2007.

Bourdieu P., Passeron J. C., Reprodukcja. Elementy teorii sytemu nauczania, przeł. E. Najman, Warszawa 2012.

Bourdieu P., Pochwała socjologii, przeł. M. Ziółkowski, „Kultura i Społeczeństwo” 57 (2013) 1, s. 3-13.

Donati P., Sociologia della riflessività. Come si entra nel dopo-moderno, Bologna 2011.

Franciszek, Adhortacja apostolska Evangelii gaudium.

Giddens A., Stanowienie społeczeństwa. Zarys teorii strukturacji, przeł. S. Amsterdamski, Poznań 2003.

Jaroszewska E., Kultura jako czynnik warunkujacy zdrowie, diagnozowanie chorób i ich leczenie, „Problemy Polityki Społecznej” 21 (2013) 2, s. 71-84.

Kwaśniewski J., Dewiacja społeczna, [w:] Encyklopedia socjologii, pod red. W. Kwaśniewicza i in., t. 1: A-J, Warszawa 1998, s. 125-129.

Lipski A., O kłopotach teoretyczno-metodologicznych pogranicza w naukach społecznych, „Problemy Polityki Społecznej” 22 (2013) 3, s. 65-82.

Ossowski S., O nauce, Warszawa 1967.

Ostrowska A., Niepełnosprawność, [w:] Encyklopedia socjologii, pod red. W. Kwaśniewicza i in., t. 2: K-N, Warszawa 1999, s. 333-336.

Parsons T., System społeczny, przeł. M. Kaczmarczyk, Kraków 2010.

Piechowski A., Edukacja i szkolenie w dziejach polskiej spółdzielczości, „Problemy Polityki Społecznej" 20 (2013) 1, s. 89-106.

Platon, Państwo, przeł. W. Witwicki, Kęty 2003.

Prüfer P., Gdzie „zamieszkuja” emocje? Odczuwanie, przeżywanie i doświadczanie przestrzeni miejskiej, [w:] Lublin 2020. Cztery oblicza przyszłości miasta, pod red. M. Sagana, K. Żuka, Lublin 2014, s. 37-45. 
Radziewicz-Winnicki A., Społeczeństwo w trakcie zmiany, Gdańsk 2005.

Safilios Rothschild C., The sociology and social psychology of disability and rehabilitation, New York 1970.

Scotti G., Disabili, [w:] Dizionario di dottrina sociale della Chiesa. Scienze sociali e Magistero, a cura di L. Ornaghi, , Milano 2004, s. 261-264.

Szczepański J., Elementarne pojęcia socjologii, Warszawa 1972.

Szmatka J., Rola społeczna, [w:] Encyklopedia socjologii, pod red. W. Kwaśniewicza i in., t. 3: O-R, Warszawa 2000, s. 321-326.

Sztompka P., Socjologia. Analiza społeczeństwa, Kraków 2012.

Śliwerski B., Diagnoza uspołecznienia publicznego szkolnictwa III RP w gorsecie centralizmu, Kraków 2013.

Śliwerski B., Wprowadzenie, [w:] Pedagogika, t. 1: Podstawy nauk o wychowaniu, Gdańsk 2006, s. VII-XII.

Znaniecki F., Ludzie teraźniejszości a cywilizacja przyszłości, Warszawa 2001.

Znaniecki F., Socjologia wychowania, t. 1, Wychowujące społeczeństwo, Warszawa 2001.

Znaniecki F., Znaczenie rozwoju świata i człowieka, przeł. J. Szacki, [w:] J. Szacki, Znaniecki, Warszawa 1986, s. 189-202. 